\title{
RESULTS OF THE STUDY OF BACKFILL STONE PORE SPACE BASED ON MICRO-CEMENT USING COMPUTER MICROTOMOGRAPHY METHODS
}

- • еонтьев, - . оном рев

D. S. Leontiev, A. A. Ponomarev

юменский госуд рственный нефтег зовый университет, г. юмень

лючевые слов : компьютерн ямикротомогр фия; т мпон жный кмень; микродур; обводненность

Key words: computed micro tomography; backfill stone; mikrodur; water cutting

сегодняшний день высок я обводненность добыв ющих скв жин является одной из основных проблем в нефтег зовой отр сли оссии. о ст тистике в мире при эксплу т ции 
нефтяных и г зовых месторождений добыв ется в семь р з больше воды, чем нефти и г 3 . редний уровень обводненности в оссии (в том числе и в п дной ибири) возр ст ет почти н $2 \%$ в год и в н стоящий период превысил отметку $80 \%[1,2]$.

резмерно высокий уровень обводненности ведет к снижению рент бельности добычи нефти и увеличению ее себестоимости, возр ст ющим 3 тр т м н утилиз цию попутно добыв емой воды, с мое гл вное - сниж ет дебит скв жин по нефти и конечную нефтеотд чу продуктивных пл стов. громное количество скв жин приходится ликвидиров ть по причине преждевременного прогрессирующего обводнения $[1,2]$.

кие геологические и технические особенности скв жин, к к н личие подошвенной (или з контурной) воды, высокопрониц емых пропл стков, нек чественное цементиров ние и коррозия обс дной колонны, способствуют ускоренному процессу обводнения $[1,2]$

сегодняшний день р зр бот но и з п тентов но большое количество технологий по огр ничению поступления воды, одн ко до конц $з$ д ч по изоляции водоприток в нефтяные и г зовые скв жины не решен .

большинстве случ ев это объясняется сложностью и р знообр зием геологических условий нефтяных и г зовых месторождений.

ри всем многообр зии причин и условий обводнения нефтяных и г зовых скв жин основным пр ктическим средством борьбы до н стоящего времени является применение обычного т мпон жного портл ндцемент . о т мпон жный цемент не может в дост точной мере отвеч ть р знообр зным требов ниям промысловой пр ктики и в определенных условиях ок зыв ется непригодным для водоизоляционных р бот ( ). н опр вдыв ет свое н зн чение лишь в случ ях литологической неоднородности продуктивного пл ст , при н личии в нем непрониц емых глинистых пропл стков и условии подъем цементного p створ до кровли одного из них, выполняющего роль естественного водонепрониц емого экр н . т ких условиях з бойные з ливки цементного р створ в большинстве случ ев ок зыв ются успешными. еобходимо отметить, что при использов нии водонепрониц емых глинистых пропл стков, при н личии нефтеносных или ч стично обводненных пропл стков, з лег ющих ниже, последние т кже подверг ются изоляции, в результ те чего почти безвозвр тно исключ ются из эксплу т ции целые уч стки нефтяной з лежи. ементные р створы м лопригодны для изоляции кр евых и н гнет емых вод, поступ ющих в скв жины по отдельным н иболее прониц емым пропл стк м, и совершенно неприемлемы в к честве средств борьбы с обводнением н месторождениях однородного тип . ля борьбы с обводнением скв жин в ук з нных условиях необходимы водоизолирующие м тери лы, способные проник ть в пористую среду изолируемых пл стов с з полнением всего пористого простр нств и обр зов ния прочного т мпон жного м тери л , устойчивого к вымыв нию водой. этом отношении цементный р створ обл д ет существенным недост тком: обл сть действия его огр ничен лишь стволом скв жины, т к к к ч стицы цемент д же тонкого помол не в состоянии проник ть в поры и микротрещины пл ст . этом случ е при проведении кту льным является применение т мпон жного сост в н основе микроцемент .

огл сно европейской кл ссифик ции микроцементом счит ется цемент с р змером ч стиц менее 20 мкм. звестны м рки Spinor ( $\mathrm{p}$ нция), икроцемент ( инляндия), нтр цем ( , имени . . енделеев ). иболее р спростр ненной м ркой микроцемент является икродур ( ерм ния, юккерхоф). икродур - это продукт воздушной сеп р ции пыли при помоле клинкерных цементов с м рк ми до «600». икродур отлич ется высокой степенью дисперсности и относится к особо тонкодисперсным вяжущим ( ). ыпуск ется 4 м рки икродур: S, F, U, X, отлич ющихся по р змер м ч стиц (т блиц 1) [3].

р ктеристики дисперсности суспензии « икродур»

\begin{tabular}{|c|c|c|c|c|c|c|}
\hline \multirow{2}{*}{ рк } & \multicolumn{7}{|c|}{ оличество ч стиц с ди метром, \% } \\
\cline { 2 - 7 } & $<2$ мкм & $<4$ мкм & $<6$ мкм & $<9,5$ мкм & $<16$ мкм & $<24$ мкм \\
\hline $\mathrm{S}$ & 17 & 34 & 49 & 68 & 90 & 95 \\
\hline $\mathrm{F}$ & 19 & 45 & 60 & 80 & 95 & - \\
\hline $\mathrm{U}$ & 25 & 55 & 78 & 95 & - & - \\
\hline $\mathrm{X}$ & 45 & 80 & 95 & - & - & - \\
\hline
\end{tabular}


ервон ч льно суспензии н основе икродур н ч ли применять для укрепления и гидроизоляции при реконструкции стен и фунд ментов п мятников рхитектуры без н рушения их рхитектурного облик, ремонте к менных и бетонных конструкций, улучшении свойств основ ний [4].

н стоящее время н его основе р зр б тыв ются т мпон жные м тери лы для водоизоляционных р бот в нефтяных и г зовых скв жин х. примеру, профессором . . лещенко ( юм ) р зр бот н сост в, включ ющий поливиниловый спирт ( ), икродур «U» и гипохлорит к льция $\mathrm{Ca}(\mathrm{Cl})_{2}$ (п тент № 2326922). . . . ник ровским и др. ( юм ) р зр бот н сост в, повыш ющий изоляцию подошвенных вод, состоящий из икродур, сульф целл , этиленгликоля и воды. . . г довой и др. ( нефти и г 3 имени . . убкин ) р зр бот н компонентный сост в из икроцемент икро, понизителя фильтр ции « - $\quad$ ", з медлителя срок схв тыв ния « - " », пеног сителя « есил-201» и воды. икродур обл д ет рядом несомненных преимуществ, именно:

- высокой проник ющей способностью (в трещины и поры р змером до 18 мкм и менее);

- седимент ционной устойчивостью (седимент ция суспензии од : икродур $=2: 1$ (по весу) не превыш ет $5 \%$ );

- высокой прочностью сформиров нного т мпон жного к мня (сроки схв тыв ния 3-4 ч с );

- быстрым н бором прочности (70\% м рочной з 48 ч сов);

- существенным снижением коэффициент фильтр ции (с $1 \times 10^{-4}$ до $\left.1 \times 10^{-7} \mathrm{~m} / \mathrm{c}\right)$;

- снижением пок з телей водопрониц емости в результ те уплотнения в тысячу р з и более;

- экологической безоп сностью;

- экономным р сходом м тери лов.

успензия икродур обл д ет текучестью, ср внимой с текучестью воды. роник ющ я способность суспензии « икродур» сопост вим с бездисперсными вяжущими.

юменском госуд рственном нефтег зовом университете $\mathrm{p}$ зр бот н т мпон жный сост в для ремонтно-изоляционных р бот в скв жин х, содерж щий микродур м рки U, полифункцион льный модифик тор, суперпл стифик тор и воду.

нный сост в обеспечив ет изоляцию воды в коллектор х любой прониц емости, их 3 крепление в прискв жинной зоне пл ст ( ), ликвид цию 3 колонных перетоков, ликвид цию приток подошвенных вод (конус ) уст новкой экр н в плоскости, ремонт эксплу т ционных колонн. олифункцион льный модифик тор, применяемый в сост ве, предст вляет собой комплексный продукт н основе полиметиленн фт линсульфон тов н трия, ст билизирующих веществ с гидрофобизирующими компонент ми, обспечив ющий повышенные требов ния к прочности и долговечности получ ющегося микродурного к мня. е содержит веществ, вызыв ющих коррозию оборудов ния.

уперпл стифик тор, доб вляемый с р зр бот нный сост в, предст вляет собой продукт н основе конденс ции н фт линсульфокислоты и форм льдегид, не содержит веществ, вызыв ющих коррозию, обл д ет ст билизирующим действием, способен увеличить подвижность т мпон жной смеси без изменения прочностных свойств, сниж ет прониц емость сформиров нного т мпон жного к мня.

бор торные исследов ния з ключ лись в определении возможности использов ния д нных ре гентов для получения твердого, з купорив ющего поровое простр нство коллектор . сследов ния проводили в четыре эт п . ервый эт п включ л определение времени обр зов ния и к честв изолирующего м тери л (т бл. 2).

пределение времени обр зов ния и кеств изолирующегом тери

\begin{tabular}{|c|c|c|c|}
\hline $\begin{array}{l}\text { ост в р бочего } \\
\text { р створ , м сс., \% }\end{array}$ & $\begin{array}{c}\text { одомикродурное } \\
\text { отношение }\end{array}$ & $\begin{array}{c}\text { ч ло } \\
\text { отверждения/ } \\
\text { конч ние } \\
\text { отверждения, ч с }\end{array}$ & $\begin{array}{c}\text { чественн я } \\
\text { х р ктеристик } \\
\text { обр зов вшегося } \\
\text { изолирующего } \\
\text { м тери л } \\
\end{array}$ \\
\hline $\begin{array}{l}\text { 1. икродур }-50 \\
\text { 2. од }-50\end{array}$ & 1 & $3,5 / 48$ & $\begin{array}{c}\text { мнеобр зный } \\
\text { м тери л } \\
\text { средней прочности }\end{array}$ \\
\hline $\begin{array}{ll}\text { 1. } & \text { икродур }-49,2 \\
\text { 2. } & \text { одифик тор }-0,8 \\
\text { 3. } & \text { уперпл стифик тор }-0,8 \\
\text { 4. } & \text { од }-49,2 \\
\end{array}$ & 1 & $3,5 / 48$ & $\begin{array}{c}\text { мнеобр зный } \\
\text { м тери л } \\
\text { средней прочности }\end{array}$ \\
\hline
\end{tabular}




\begin{tabular}{|c|c|c|c|}
\hline $\begin{array}{l}\text { ост в р бочего } \\
\text { р створ , м сс., \% }\end{array}$ & $\begin{array}{c}\text { одомикродурное } \\
\text { отношение }\end{array}$ & $\begin{array}{c}\text { ч ло } \\
\text { отверждения/ } \\
\text { конч ние } \\
\text { отверждения, ч с }\end{array}$ & $\begin{array}{c}\text { чественн я } \\
\text { х р ктеристик } \\
\text { обр зов вшегося } \\
\text { изолирующего } \\
\text { м тери л } \\
\end{array}$ \\
\hline $\begin{array}{l}\text { 1. } \quad \text { икродур }-49,1 \\
\text { 2. } \text { одифик тор - } 0,9 \\
\text { 3. уперпл стифик тор }-0,9 \\
\text { 4. } \text { од }-49,1\end{array}$ & 1 & $4 / 48$ & $\begin{array}{c}\text { рочный } \\
\text { к мнеобр зный } \\
\text { м тери л }\end{array}$ \\
\hline $\begin{array}{ll}\text { 1. } & \text { икродур }-49 \\
\text { 2. } & \text { одифик тор - } 1 \\
\text { 3. } & \text { уперпл стифик тор }-1 \\
\text { 4. } & \text { од }-49 \\
\end{array}$ & 1 & $4 / 48$ & $\begin{array}{c}\text { рочный } \\
\text { к мнеобр зный } \\
\text { м тери л }\end{array}$ \\
\hline $\begin{array}{ll}\text { 1. } & \text { икродур }-48,9 \\
\text { 2. } & \text { одифик тор }-1,1 \\
\text { 3. } & \text { уперпл стифик тор }-1,1 \\
4 . & \text { од }-48,9 \\
\end{array}$ & 1 & $4 / 48$ & $\begin{array}{c}\text { рочный } \\
\text { к мнеобр зный } \\
\text { м тери л }\end{array}$ \\
\hline $\begin{array}{ll}\text { 1. } & \text { икродур }-48,8 \\
\text { 2. } & \text { одифик тор - } 1,2 \\
\text { 3. } & \text { уперпл стифик тор }-1,2 \\
\text { 4. } & \text { од }-48,8 \\
\end{array}$ & 1 & $4 / 48$ & $\begin{array}{c}\text { рочный } \\
\text { к мнеобр зный } \\
\text { м тери л }\end{array}$ \\
\hline $\begin{array}{ll}\text { 1. } & \text { икродур }-48,7 \\
\text { 2. } & \text { одифик тор }-1,3 \\
\text { 3. } & \text { уперпл стифик тор }-1,3 \\
\text { 4. } & \text { од }-48,7 \\
\end{array}$ & 1 & $4 / 48$ & $\begin{array}{c}\text { рочный } \\
\text { к мнеобр зный } \\
\text { м тери л }\end{array}$ \\
\hline $\begin{array}{ll}\text { 1. } & \text { икродур }-48,6 \\
\text { 2. } & \text { одифик тор - } 1,4 \\
\text { 3. } & \text { уперпл стифик тор }-1,4 \\
\text { 4. } & \text { од }-48,6 \\
\end{array}$ & 1 & $4 / 48$ & $\begin{array}{c}\text { рочный } \\
\text { к мнеобр зный } \\
\text { м тери л }\end{array}$ \\
\hline $\begin{array}{ll}\text { 1. } & \text { икродур -48,5 } \\
\text { 2. } & \text { одифик тор }-1,5 \\
\text { 3. уперпл стифик тор }-1,5 \\
\text { 4. } \text { од }-48,5\end{array}$ & 1 & $4 / 48$ & $\begin{array}{c}\text { рочный } \\
\text { к мнеобр зный } \\
\text { м тери л }\end{array}$ \\
\hline
\end{tabular}

торым эт пом р бот являлось исследов ние кинем тической вязкости и ст тического н пряжения сдвиг т мпон жных р створов. сследов ния проводились н рот ционном вискозиметре Model 900. езульт ты исследов ний предст влены в т блице 3.

езульт ты исследов ний кинем тической вязкости и ст тического н пряжения сдвиг т мпон жных р створов

\begin{tabular}{|c|c|c|c|c|c|c|c|c|c|}
\hline \multirow{3}{*}{$\begin{array}{c}\text { ост в р бочего р створ } \\
\text { м сс., } \%\end{array}$} & \multicolumn{7}{|c|}{ яЗКость, с } & \multirow{3}{*}{$\begin{array}{l}10 \\
\text { сек }\end{array}$} & \multirow{3}{*}{$\begin{array}{c}10 \\
\text { мин }\end{array}$} \\
\hline & \multicolumn{7}{|c|}{ стот вр щения, об/мин } & & \\
\hline & 300,0 & 200,0 & 100,0 & 60,0 & 30,0 & 6,0 & 3,0 & & \\
\hline $\begin{array}{ll}1 . & \text { икродур }-50 \\
2 . & \text { од }-50\end{array}$ & 181,0 & 174,0 & 162,0 & 117,0 & 91,0 & 45,0 & 29,0 & 18,1 & 32,6 \\
\hline $\begin{array}{ll}\text { 1. } & \text { икродур }-49,2 \\
\text { 2. } & \text { одифик тор }-0,8 \\
\text { 3. } \text { уперпл стифик тор }-0,8 \\
\text { 4. } \text { од }-49,2 \\
\end{array}$ & 63,0 & 55,0 & 44,0 & 39,0 & 40,0 & 22,7 & 16,8 & 11,2 & 13,4 \\
\hline $\begin{array}{ll}\text { 1. } & \text { икродур - 49,1 } \\
\text { 2. } & \text { одифик тор - } 0,9 \\
\text { 3. } & \text { уперпл стифик тор }-0,9 \\
\text { 4. } & \text { од }-49,1 \\
\end{array}$ & 64,0 & 55,0 & 44,0 & 38,0 & 34,0 & 21,5 & 16,6 & 9,8 & 12,1 \\
\hline $\begin{array}{l}\text { 1. } \\
\text { 2. } \text { окродури }-49 \\
\text { 3. уперпл тор }-1 \\
\text { 4. од }-49\end{array}$ & 66,0 & 56,0 & 44,0 & 38,0 & 33,0 & 21,2 & 16,4 & 8,3 & 11,0 \\
\hline $\begin{array}{ll}\text { 1. } & \text { икродур }-48,9 \\
\text { 2. } & \text { одифик тор }-1,1 \\
\text { 3. } \text { уперпл стифик тор }-1,1 \\
\text { 4. } \text { од }-48,9 \\
\end{array}$ & 59,0 & 51,0 & 40,0 & 35,0 & 30,0 & 20,2 & 16,3 & 7,4 & 11,6 \\
\hline $\begin{array}{ll}\text { 1. } & \text { икродур }-48,8 \\
\text { 2. } & \text { одифик тор }-1,2 \\
\text { 3. } & \text { уперпл стифик тор }-1,2 \\
\text { 4. } & \text { од }-48,8 \\
\end{array}$ & 54,0 & 47,0 & 37,0 & 34,0 & 29,0 & 19,0 & 15,0 & 6,8 & 8,2 \\
\hline
\end{tabular}


родолжение т бл. 3

\begin{tabular}{|c|c|c|c|c|c|c|c|c|c|}
\hline \multirow{3}{*}{$\begin{array}{c}\text { ост в р бочего р створ } \\
\text { м сс., } \%\end{array}$} & \multicolumn{7}{|c|}{ ЯзКость, с } & \multirow{3}{*}{$\begin{array}{c}10 \\
\text { cek }\end{array}$} & \multirow{3}{*}{$\begin{array}{c}10 \\
\text { мин }\end{array}$} \\
\hline & \multicolumn{7}{|c|}{ стот вр щения, об/мин } & & \\
\hline & 300,0 & 200,0 & 100,0 & 60,0 & 30,0 & 6,0 & 3,0 & & \\
\hline $\begin{array}{ll}\text { 1. } & \text { икродур }-48,7 \\
\text { 2. } & \text { одифик тор }-1,3 \\
\text { 3. } & \text { уперпл стифик тор }-1,3 \\
\text { 4. } & \text { од }-48,7\end{array}$ & 53,0 & 45,0 & 36,0 & 31,0 & 28,0 & 18,4 & 13,9 & 6,4 & 9,6 \\
\hline $\begin{array}{ll}\text { 1. } & \text { икродур }-48,6 \\
2 . & \text { одифик тор }-1,4 \\
\text { 3. } & \text { уперпл стифик тор }-1,4 \\
4 . & \text { од }-48,6\end{array}$ & 50,0 & 42,0 & 33,0 & 29,0 & 24,0 & 16,5 & 12,6 & 6,5 & 9,5 \\
\hline $\begin{array}{ll}\text { 1. } & \text { икродур }-48,5 \\
\text { 2. } & \text { одифик тор }-1,5 \\
\text { 3. } & \text { уперпл стифик тор }-1,5 \\
\text { 4. } & \text { од }-48,5\end{array}$ & 63,0 & 54,0 & 44,0 & 38,0 & 34,0 & 22,5 & 16,4 & 7,3 & 12,5 \\
\hline
\end{tabular}

ретьим эт пом р бот являлось исследов ние обр зов вшегося т мпон жного к мня н изгиб и сж тие через 2, 7, 28 суток твердения. езульт ты исследов ний предст влены в т блице 4 .

блиц 4

сследов ние обр зов вшегося т мпон жного к мня н изгиб и сж тие

\begin{tabular}{|c|c|c|c|c|c|c|}
\hline \multirow{2}{*}{$\begin{array}{c}\text { ост в р бочего р створ } \\
\text { м сс., } \%\end{array}$} & \multicolumn{3}{|c|}{ згиб, } & \multicolumn{3}{|c|}{ ж тие, } \\
\hline & 2 дня & 7 дней & 28 дней & 2 дня & 7 дней & 28 дней \\
\hline $\begin{array}{ll}1 . & \text { икродур }-50 \\
2 . & \text { од }-50\end{array}$ & 2,74 & 6,47 & 6,89 & 7,26 & 11,63 & 13,71 \\
\hline $\begin{array}{ll}\text { 1. } & \text { икродур }-49,2 \\
2 . & \text { одифик тор - } 0,8 \\
\text { 3. } & \text { уперпл стифик тор }-0,8 \\
4 . & \text { од }-49,2 \\
\end{array}$ & 2,81 & 6,37 & 6,83 & 7,86 & 12,38 & 14,10 \\
\hline $\begin{array}{ll}\text { 1. } & \text { икродур }-49,1 \\
2 . & \text { одифик тор - } 0,9 \\
\text { 3. } & \text { уперпл стифик тор }-0,9 \\
4 . & \text { од }-49,1 \\
\end{array}$ & 2,92 & 6,53 & 7,01 & 7,88 & 12,42 & 14,37 \\
\hline $\begin{array}{ll}\text { 1. } & \text { икродур }-49 \\
\text { 2. } & \text { одифик тор }-1 \\
\text { 3. } \\
\text { 4. } \\
\text { од }-49\end{array}$ & 3,03 & 6,68 & 7,19 & 7,88 & 12,48 & 14,53 \\
\hline $\begin{array}{ll}\text { 1. } & \text { икродур }-48,9 \\
\text { 2. } & \text { одифик тор }-1,1 \\
\text { 3. } \text { уперпл стифик тор }-1,1 \\
\text { 4. } \text { од }-48,9\end{array}$ & 3,64 & 7,31 & 7,84 & 8,10 & 14,34 & 16,24 \\
\hline $\begin{array}{ll}\text { 1. } & \text { икродур }-48,8 \\
2 . & \text { одифик тор - } 1,2 \\
\text { 3. } & \text { уперпл стифик тор }-1,2 \\
4 . & \text { од }-48,8 \\
\end{array}$ & 3,50 & 7,21 & 7,78 & 8,28 & 14,53 & 16,73 \\
\hline $\begin{array}{ll}\text { 1. } & \text { икродур - 48,7 } \\
\text { 2. } & \text { одифик тор - } 1,3 \\
\text { 3. } & \text { уперпл стифик тор }-1,3 \\
\text { 4. } & \text { од }-48,7\end{array}$ & 3,59 & 7,34 & 7,92 & 8,46 & 15,54 & 17,51 \\
\hline $\begin{array}{ll}\text { 1. } & \text { икродур }-48,6 \\
\text { 2. } & \text { одифик тор }-1,4 \\
\text { 3. } & \text { уперпл стифик тор }-1,4 \\
\text { 4. } & \text { од }-48,6\end{array}$ & 3,81 & 7,60 & 8,23 & 8,83 & 16,24 & 18,46 \\
\hline $\begin{array}{ll}\text { 1. } & \text { икродур }-48,5 \\
\text { 2. } & \text { одифик тор }-1,5 \\
\text { 3. } & \text { уперпл стифик тор }-1,5 \\
\text { 4. } & \text { од }-48,5\end{array}$ & 4,33 & 8,16 & 8,80 & 9,61 & 16,92 & 18,91 \\
\hline
\end{tabular}

лее вторы предложили применить метод компьютерной микротомогр фии и исследов ть поровое простр нство сформиров вшегося т мпон жного к мня.

омпьютерн я микротомогр фия или микро- - это реконструкция бин рных моделей рентгеновских изобр жений в трехмерное простр нство [5].

ринцип действия прибор предст влен н рисунке 1. бр зец уст н влив ется в ск нер н предметный столик, который в ходе ск ниров ния вр щ ется, в этот момент через обр зец проходят рентгеновские лучи, испуск емые источником, ост вляя н приемнике (к ме- 
ре) теневые проекции. ри к ждом повороте фиксируется отдельн я проекция (отдельное двумерное изобр жение, отвеч ющее интенсивности рентгеновского излучения после прохождения последнего через изуч емый обр зец, н зыв ется теневой проекцией).

ис. 1. ринцир ботымикротомогр ф
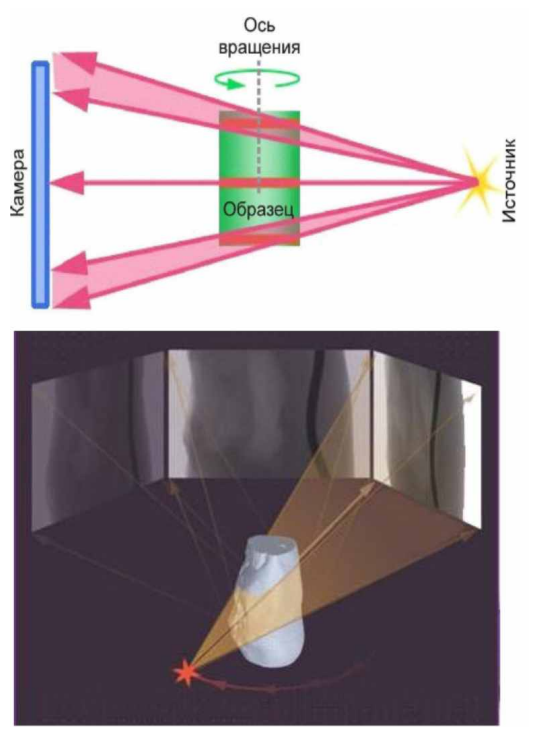

ркость (р зличные гр д ции серого) н рентгеновской теневой проекции отр ж ет осл бление рентгеновского излучения з счет эффектов р ссеив ния и поглощения сигн л , прошедшего через обр зец.

сл бление будет $з$ висеть от плотности и толщины изуч емого объект , т кже от эффективного томного номер (Zэф), из которого состоит исследуемый обр зец. писыв ется этот эффект з коном мберт - ep, определяющим осл бление монохром тического пучк свет при р спростр нении его в поглощ ющей среде. кон выр ж ется формулой

$$
\mathrm{I}(\mathrm{x})=I_{0} e^{(-\mu x)}
$$

где $I_{0}-$ н ч льн я интенсивность рентгеновского излучения; $x$ - толщин слоя веществ , через которое проходит излучение; - пок з тель поглощения среды. случ е, когд ск нируемый объект не гомогенен по своему сост ву, т ковы пр ктически все горные породы, то ур внение приобрет ет вид

$$
\mathrm{I}(\mathrm{x})=I_{0} e^{\left(-\sum_{i} \mu_{i} x_{i}\right)}
$$

где к ждому инкременту $I$ соответствует отдельный м тери л с определенным пок 3 телем поглощения $\mu_{i}$ и линейной длиной $x_{i}$. ри прохождении рентгеновского излучения через к кой-либо м тери л уровень поглощения излучения может быть сопряжен с четырьмя вид ми вз имодействия: фотоэлектрическим поглощением, комптоновским р ссеянием, обр зов нием электрон-позитронных п р и когерентным р ссеянием елея. случ е с изучением геологических объектов, когд применяются источники излучения с энергией до 100 кэ , основным процессом, определяющим осл бление рентгеновского излучения, будет фотоэлектрическое поглощение.

осле ск ниров ния в ходе реконструкции проекции преобр зуются в срезы толщиной один воксель, из которых $з$ тем строится 3D модель обр зц и н лизируется. ксим льный р змер обр зц для системы SkyScan 1172 по длине/ширине не должен превыш ть 64 мм. ксим льн я высот - 70 мм [5].

ля проведения исследов ний был выбр н т мпон жный к мень, приготовленный по рецептуре № 2. спользуемое оборудов ние для проведения н лиз по микротомогр фии: Skyscan 1172 со ст нд ртным п кетом прогр мм (Nrecon, CTan, Ctvol, Data Viewer). бр зец сним лся при следующих режим х ск ниров ния: н пряжение 100 kV, сил ток 100 uA, оптим льное р зрешение для обр зц было выбр но 3,95 мкм/pxl. 
3 обр зц вырез лось по 3 кубик с р зных ч стей его объем , з тем по кубик м определял сь пористость, и р ссчитыв лись эквив лент-ди метры. остроены 3D модели порового простр нств кубиков, произведены р звертки обр зцов по трем плоскостям поперечного сечения, к к обр зц в целом, т к и кубиков в отдельности. звертк обр зц по трем плоскостям поперечного сечения предст влен н рисунке 2 .

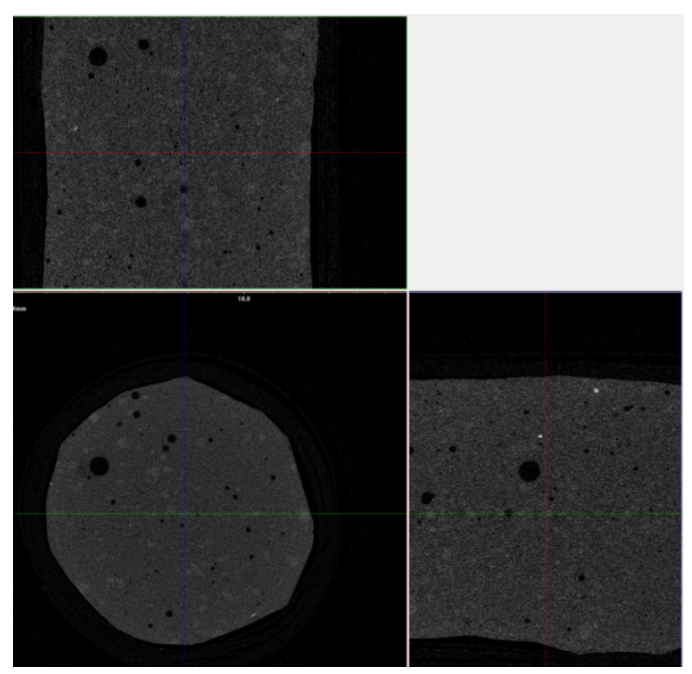

ис. 2. звертк обр зи по трем плоскостям поперечного сечения

звертки кубов № 1, 2 и 3 по трем плоскостям поперечного сечения предст влены н рисунке 3.
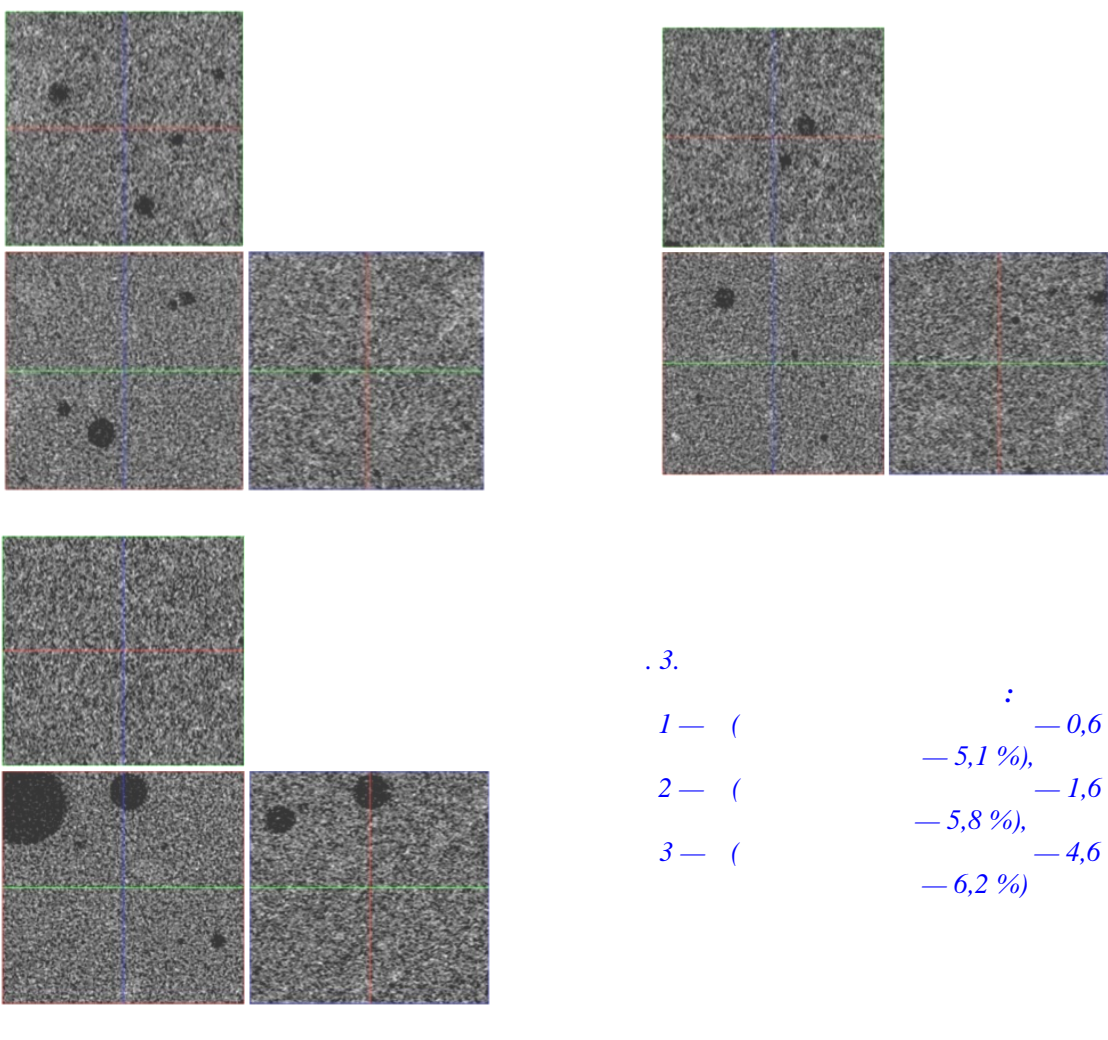

ис. 3. звертки кубов по трем плоскостям поперечного сечения:

№ 1 - (открыт я пористость -0,6\%, изолиров нн я-5,1\%),

№ $2-6$ (открыт я пористость - $1.6 \%$, изолиров нн я-5,8\%),

№ 3 - в (открыт я пористость -4,6\% изолиров нн я-6,2\%)

устотное простр нство 3D модели кубов № 1, 2 и 3 предст влено н рисунке 4 . 

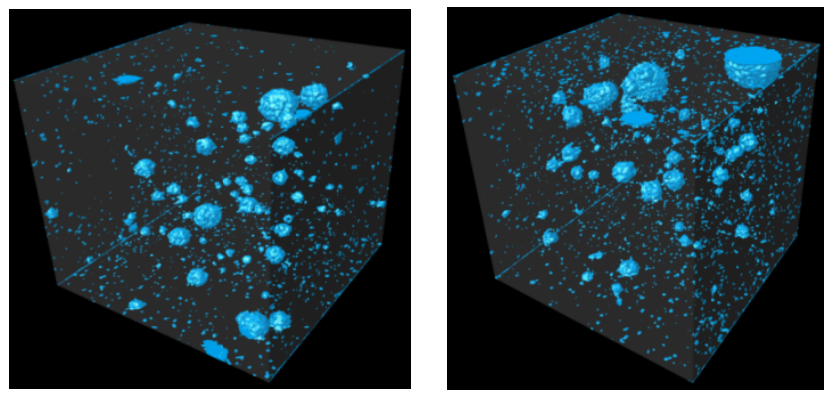

6

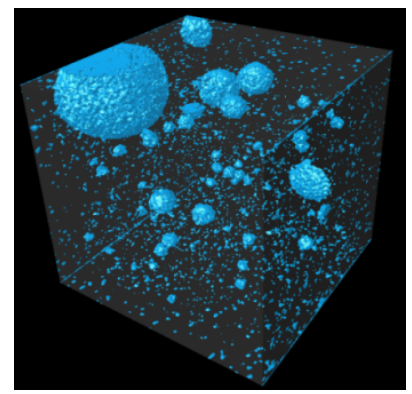

B

ис. 4. устотное простр нство 3D модели кубов № 1( ), № 2 (б), № 3(в)

нтерв лы эквив лент-ди метров пор (мкм) и их доля от общей пористости (\%) кубов № 1, 2 и 3 предст влены н рис. 5-7.

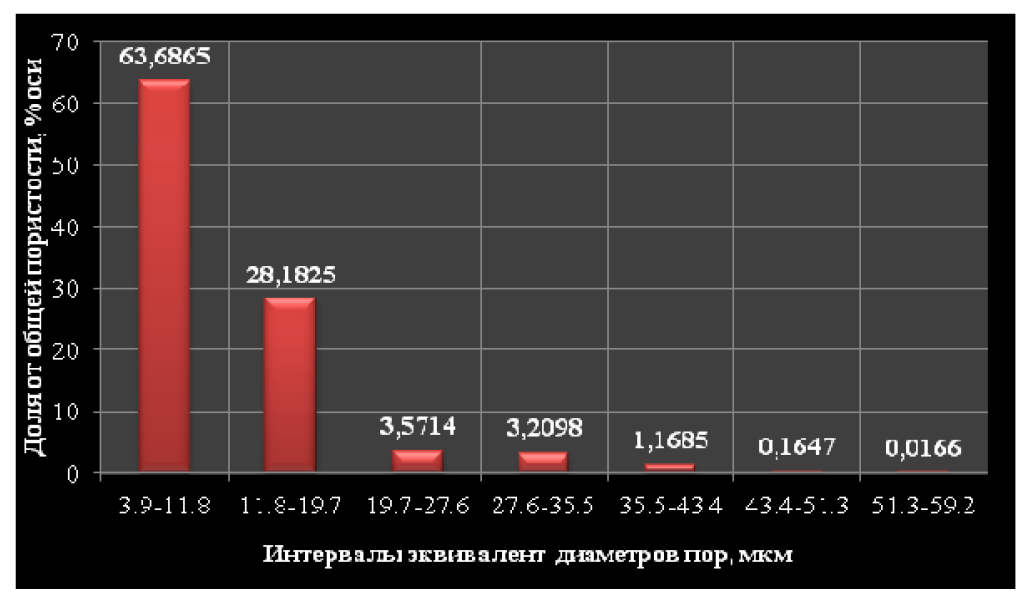

ис. 5. нтерв лы эквив лент-ди метров пор (мкм) и их доля от общей пористости (\%) куб № 1

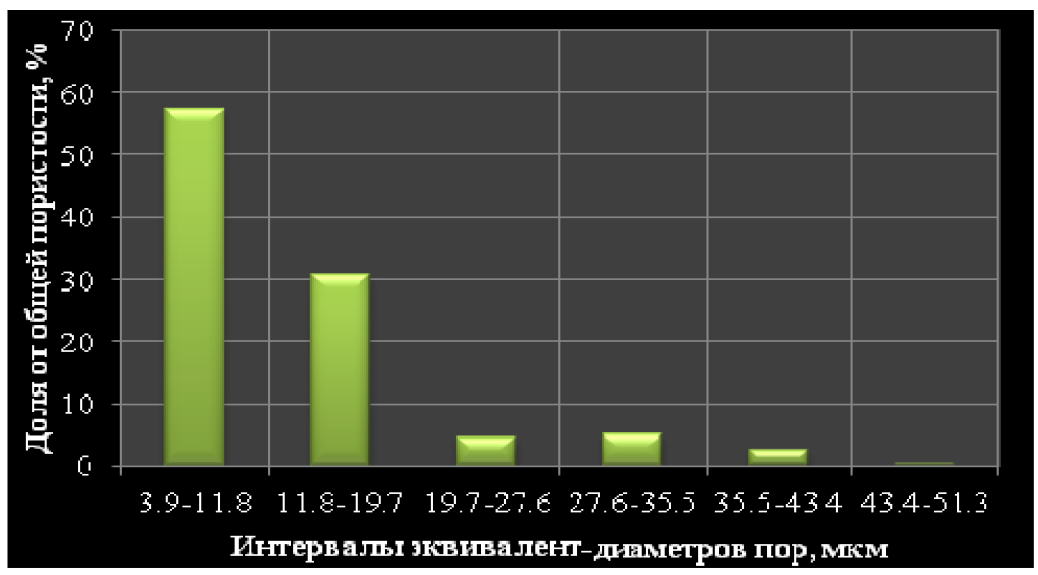

ис. 6. нтерв лы эквив лент-ди метров пор (мкм) и их доля от общей пористости (\%) куб № 2 


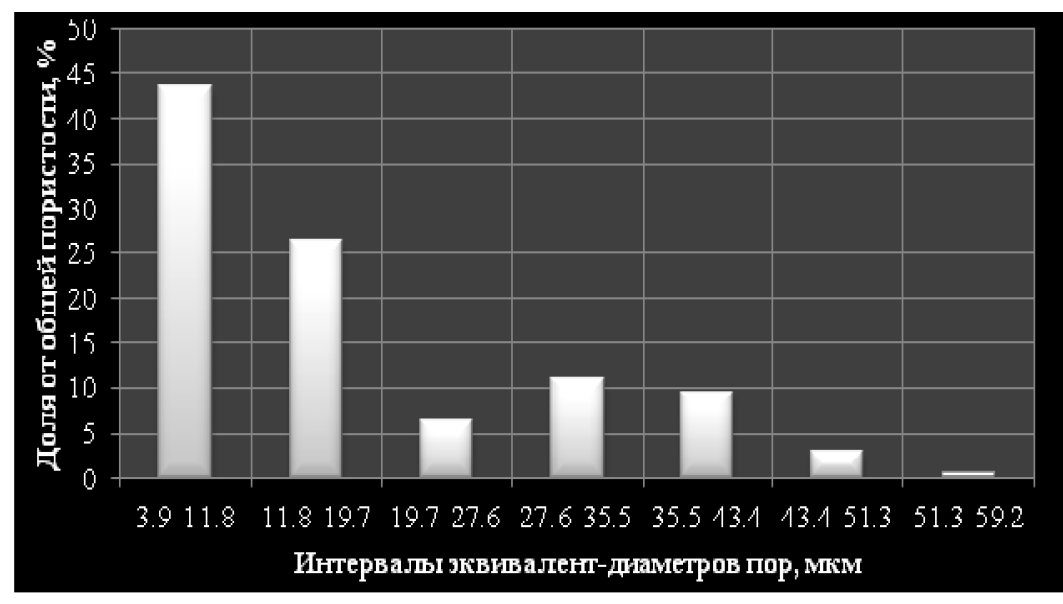

ис. 7. нтерв лы эквив лент-ди метров пор (мкм)

и их доля от общей пористости (\%) куб № 3

ким обр зом, в н стоящее время н иболее р спростр ненным средством огр ничения поступления воды в нефтяные и г зовые скв жины является применение т мпон жного цемент . дн ко грубодисперсную систему з труднительно, порой и невозможно з к ч ть в пористую среду, д же если коллектор обл д ет высокой прониц емостью. $\quad$ иболее приемлемым является применение т мпон жного р створ н основе микроцемент .

н лизируя полученные результ ты исследов ния т мпон жного к мня н основе икродур методом компьютерной микротомогр фии через двое суток твердения, можно сдел ть вывод: пористость его очень низк я и сост влен по большей ч сти изолиров нными пор ми, что говорит о пр ктически полном отсутствии прониц емости д нного цемент .

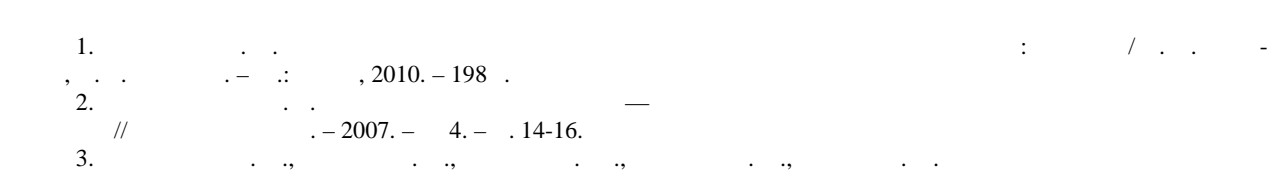
т мпон жных р створов н основе микроцементов для ремонтно-изоляционных р бот // тери лы XV еждун родной н учно-пр ктическ я конференции « фиры целлюлозы и кр хм л, другие новые химические ре генты и композиционные м тери лы к к основ успешного сервис и высокого к честв технологических жидкостей для строительств , эксплу т ции и к пит льного ремонт нефтяных и г зовых скв жин». - узд ль: 2011. - . 208-211.

4. йд ков . . рименение м тери лов «Mikrodur» для инъекционных р бот при укреплении грунтов и усилении конструкций. // етро и тоннели. - 2005. - № 6. - . 34-38.

5. оном рев . ., в тский . . етоды применения компьютерной микротомогр фии в геологии // 3вестия высших учебных з ведений. ефть и г з. - 2015. - № 3 - . 29-33.

6. нченко . ., рченко . . собо тонкодисперсное минер льное вяжущее « икродур»: свойств, технология и перспективы использов ния // троительные м тери лы. - 2005. - № 10. - . 76-78.

7. лексеев . . икродур - инъекционное минер льное вяжущее и опыт его применения / еждун родн я н учно-техническ я конференция « ехнологии, оборудов ние, м тери лы, норм тивное обеспечение и мониторинг для тоннельного строительств и подземных ч стей высотных зд ний». - $\quad . \quad$ оннельн я ссоци ция оссии, 2006. $198-200$

8. озуля . ., лещенко . ., ейхм н . ., 6 ев . . еория и пр ктик выбор технологий и м тери лов для ремонтно-изоляционных р бот в нефтяных и г зовых скв жин х: чебное пособие. - юмень: юм , 2002. $-138 \mathrm{c}$.

ведения об втор $x$

еонтвев митрий ергеевич, спир нт, ссистент к федры "урение нефтяных и г зовых скв жин», юменский госуд рственный нефтег зовый университет, г. юмень, тел. 8(3452)200989, e-mail: leonfob@mail.ru

оном рев ндрей лекс ндрович, $л$ бор нт учебно-н учной геохимической л бор тории, специ лист по вопрос м компьютерной микротомогр фии. юменский госуд рственный нефтег зовый университет, г. юмень, тел.89829313122, е-mail:ponomarev94@mail.ru
Information about the authors

Leontiev D. S., postgraduate, assistant of the chair «Drilling of oil and gas wells», Tyumen State Oil and Gas University, phone: 8(3452)200989, e-mail: leonfob@mail.ru

Ponomarev A. A., lab assistant of the educationalscientific geochemical laboratory, specialist in problems of computer microtomography, Tyumen State Oil and Gas University, phone: 8(3452)200989, e-mail: leonfob@mail.ru 